\title{
ABCD1 Gene Mutation
}

National Cancer Institute

\section{Source}

National Cancer Institute. ABCD1 Gene Mutation. NCI Thesaurus. Code C147902.

A change in the nucleotide sequence of the ABCD1 gene. 